\title{
The effect of biochar and compost from urban organic waste on plant biomass and properties of an artificially copper polluted soil
}

\author{
Eliana Cárdenas Aguiar, Gabriel Gascó, Jorge Paz-Ferreiro, Ana Méndez
}

\begin{abstract}
A B S T R A C T
Soil contamination with copper is a global issue, in particular in soils with a history of fertilizers, fungicides or municipal waste amendment. Several remediation techniques have been investigated to reduce the environmental impact of Cu-contaminated soil, including the use of organic amendments such as composts and biochars, which can bound part of the soluble fraction of the metal. The objective of this work is to study the effect of biochar and biochar plus compost addition on copper mobility, soil microbial biomass and growth of different plant species following remediation of a soil spiked with copper (1000 mg Cu kg-1). The contaminated soil was treated with $10 \mathrm{wt} \%$ of biochar or biochar plus compost. Different plant species (mustard, cress and ryegrass) were grown in the soil during 4 weeks. A significant reduction on the mobile form of $\mathrm{Cu}$ was observed in soils treated with biochar and biochar plus compost. The highest microbial biomass values were obtained in samples treated with biochar plus compost. After cress growth, the microbial biomass of soil treated with biochar plus compost was similar to that of non-polluted soil. The germination test showed increased root length in the amended soils compared to the contaminated soils. With respect to biomass growth of vegetable species in copper polluted soil, only ryegrass presented a satisfactory growth in the contaminated soil without the biochar treatment. For mustard and cress, biomass growth was only observed following biochar addition.
\end{abstract}

\section{Introduction}

Soil contamination is a global issue, constituting a threat to ecosystems, farming production and human wellbeing. When soil contamination is produced by heavy metals, impacts are significant, as they are non-biodegradable compounds. Important consequences of heavy metal contamination comprise variations on $\mathrm{pH}$, high electrical conductivity or microbial properties alteration (Vacca et al., 2012; Yang et al., 2012). Keeping in mind that metals distribution may vary along time and with soil conditions (Lu et al., 2005), undesirable effects such as incorporation to higher level of the food chain, water contamination and human health affectations are granted. Agricultural use of copper fungicides has led to a high level of copper in many soils around the world which persists and further accumulates in the topsoil under current management practices. Increasing copper concentrations in soils has negative effects, including reducing plant biomass (Kolbas et al., 2015; Mc Bridge et al., 1981) and affecting soil biodiversity. As an example of the latter, $\mathrm{Cu}$ contamination can reduce the abundance and biodiversity of soil organisms, thus inhibiting the activity of hydrocarbon-degrading microorganisms and leading to an impairment of the $\mathrm{C}$ and $\mathrm{N}$ cycles (Mackie et al., 2014).

Coupled to this, urban organic waste is increasingly produced as a consequence of urbanization and urban sprawl. Most urban wastes are disposed in landfills, creating a series of problems which include the emission of greenhouse gases, soil contamination, leaching of pollutants to groundwater and the production of obnoxious odors. Urban organic wastes could be composted, but composts are not harmless and could pose several risks to human. This includes exposure associated to atmospheric dispersion and the presence of pathogens in the compost (Déportes et al., 1995). Moreover, compost addition to soil in Spain has resulted in the accumulation of total and available heavy metals (Ramos, 2006) and thus, better valorization alternatives need to be explored. The use of compost in agriculture can lead not only to increased metal concentrations in the crops or in the groundwater but also to 
building up soil salt content (Hargreaves et al., 2008).

Several remediation techniques have been investigated to reduce the environmental impact of metal contaminated soils (Bolan et al., 2014). Stabilization/solidification method is a remediation technology defined as the process of using non-toxic substances (organic and inorganic) for minimizing the solubility of heavy metal contaminants in soils and thus reducing its leachability to the groundwater and the environment. Several soil amendments have been used successfully for immobilization of metals, including lime or phosphate (Cao et al., 2008) and organic materials from different origins, including compost (Vaca-Paulin et al., 2006; Karami et al., 2011; Venegas et al., 2015). More recently, biochar, the carbonaceous product obtained by biomass thermal treatment (pyrolysis) in absence or with a limited amount of oxygen $(<1 \%)$ (Lehmann et al., 2011), has been studied as amendment for the remediation of heavy metal contaminated soils (Karami et al., 2011; Paz-Ferreiro et al., 2014).

According to Zhang et al. (2013) biochar has several impacts in the mobility of heavy metals. Studies performed in a nicked polluted soil demonstrated that the addition of biochar reduces the quantity of mobile, leached and also bioavailable nickel (Méndez et al., 2014). Lu et al. (2014) proposed that biochar effect on the metal mobility is partially due to superficial adsorption combined with the interchange of ions between the metals and calcium, magnesium, sodium and potassium ions. Carbonates phosphates and sulphur also contribute to the stabilization of the soil pollutant (Park et al., 2013).

Paz-Ferreiro et al. (2014) concluded that biochar as amendment can improve plants growth with some additional effects such as (i) improve biological activity of soil and at the same time that decrease the toxicity of the soil, (ii) biochar acts like a slow release fertilizer and increases microbial biomass, (iii) regulate soil $\mathrm{pH}$. Furthermore, other benefits, including carbon sequestration, binding of nutrients and improved soil water retention capacity (Liang et al., 2014; Méndez et al., 2012; Paz-Ferreiro et al., 2012) have also been reported frequently in the literature.

A diverse number of feedstocks have been used to prepare biochars suitable for the remediation of heavy metals in soils (Gascó et al., 2016a; Méndez et al., 2014; Paz-Ferreiro et al., 2014). However, to our knowledge, there is a lack of studies using urban waste biochar for the remediation of polluted soils.

Thus, our literature review has identified the prospect to transform urban organic wastes into biochar, in order to divert the amount of residues disposed in landfills and remediate heavy metal polluted soils. The main objective of the present work is to determine the efficiency of biochar and biochar plus compost addition in the remediation of a copper-spiked soil. The soil was grown with different plants species in order to determine the prospects for revegetation and study the risk of metal transfer to the plants.

\section{Materials and methods}

\subsection{Raw materials}

The selected soil (C) was sampled in El Fresno town (Ávila, Spain, latitude: $40^{\circ} 37^{\prime} \mathrm{N}$, longitude: $4^{\circ} 44^{\prime} \mathrm{W}$, altitude: $1073 \mathrm{~m}$ ) and it is classified as Typic Xerofluvent according to Soil Taxonomy (Soil Survey Staff, 2014).

Organic waste $(R)$ was produced in a solid waste treatment plant located in the North of Spain. After its reception, solid wastes were pretreated with different mechanical equipment, such as trommels in order to separate the organic matter of other materials. Biochar (B) was obtained by thermal treatment of $\mathrm{R}$ in an inert atmosphere in a Heron $12-\mathrm{PR} / 300$ series $8 \mathrm{~B}$ muffle, at a heating rate $10^{\circ} \mathrm{C} \mathrm{min}-1$ until reaching $500^{\circ} \mathrm{C}$. This temperature was maintained for $1 \mathrm{~h}$.

\subsection{Raw materials characterization}

Soil (S), compost of urban organic waste (R) and corresponding biochar (B) were air-dried, crushed and sieved through a $2 \mathrm{~mm}$ mesh prior to analyses. Raw materials were characterized, with the following properties being measured:

Soil texture was determined following the methodology of Bouyoucos (1962). pH and electrical conductivity (EC) were determined with a soil:water ratio of 1:2.5 using a Crison micro-pH 2000 and a Crison 222 conductivimeter (Alella, Spain) respectively. Cation exchange capacity (CEC) was determined in $\mathrm{NH}_{4} \mathrm{OAc} / \mathrm{HOAc}$ at $\mathrm{pH} 7.0$ (Sumner and Miller, 1996). Organic carbon $\left(\mathrm{C}_{\mathrm{oxi}}\right)$ oxidized with dichromate was determined by the Walkley-Black method (Nelson and Sommers, 1996) and soluble organic carbon ( $C_{\text {oxi solu- }}$ ble) was determined after sampling the extract in a ratio sample:water $1: 10(\mathrm{~m} / \mathrm{v})$ following $1 \mathrm{~h}$ agitation. After that, $\mathrm{C}_{\text {oxi soluble }}$ was determined according to the Walkley-Black method.

Kjeldahl nitrogen content $\left(\mathrm{N}_{\text {Kjeldahl }}\right)$ was done by Kjeldahl's method (Bremner et al., 1996) and phosphorous (P) was analyzed with Shimadzu UV-1203 UV spectrophotometer at $430 \mathrm{~nm}$ using Olsen's method (Watanabe and Olsen, 1965).

Thermal analyses (TG, dTG and DTA) of samples $R$ and B were performed in a thermobalance Labsys Setaram. Samples (40-50 mg) were heated until $850^{\circ} \mathrm{C}$ in an air atmosphere with a $40 \mathrm{~mL} \mathrm{~min}{ }^{-1}$ flux using a heating rate of $15^{\circ} \mathrm{C}$ per minute (Méndez et al., 2014). Proximate analysis was determined by thermogravimetry using a Labsys Setaram equipment (Caluire, France). The sample was heated to $600^{\circ} \mathrm{C}$ under $\mathrm{N}_{2}$ with a $30^{\circ} \mathrm{C} \mathrm{min}{ }^{-1}$ heating rate. Moisture content was calculated as the weight loss from the initial temperature to $150^{\circ} \mathrm{C}$. Volatile matter (VM) was determined as the weight loss from 150 to $600^{\circ} \mathrm{C}$ under $\mathrm{N}_{2}$ atmosphere. At this temperature, air was introduced and fixed carbon (FC) was calculated as the weight produced when the final sample was burnt. The ash was determined as the final weight of the samples.

All experiments were performed in triplicate.

\subsection{Preparation of polluted soil and treatments}

The sampled soil was contaminated with copper at a concentration of $1000 \mathrm{mg} \mathrm{Cu}^{2+} \mathrm{kg}^{-1}$ of soil and uncontaminated soil (C) and contaminated soil were incubated during 3 weeks at $20^{\circ} \mathrm{C}$. The copper source was copper sulphate $\left(\mathrm{CuSO}_{4} \cdot 5 \mathrm{H}_{2} \mathrm{O}\right)$. The period of incubation was chosen as it is common in studies on heavy metal mobility (Oorts et al., 2008) or soil biological properties (Creamer et al., 2014).

After the incubation period, contaminated soil (Cont) was treated with a $10 \%$ of biochar (Cont $+B$ ) and with $10 \%$ of biochar and $5 \%$ of compost (Cont $+B+R)$.

\subsection{Germination test}

Bioassay of seed germination and early stage seedling growth is a simple and commonly used ecotoxicological text that is starting to be used to study the biochar effect in soils (Méndez et al., 2015) and, although several species have traditionally been used to evaluate phytotoxicity, there are no standardized plant species in use for this kind of assay (Gascó et al., 2016b). The phytotoxicity test was made following the procedure described by Zucconi et al. (1985) with 9 species in order to have a better understanding of biochar effects: Cress (Lepidium sativum), white mustard (Sinapsis alba), lentil (Lens culinaris), lettuce (Lactuca sativa), tomato (Lycopersicon esculentum), basil (Ocymum basilicum), English ryegrass (Lolium perenne), wheat (Triticum aestivum) and barley (Hordeum vulgare) (Table 1).

The test was carried out on filter paper in Petri dishes. Five 
milliliters of aqueous extract $(1 / 10 \mathrm{w} / \mathrm{v})$ of biochar, urban organic waste compost (R), uncontaminated soil (C), contaminated soil (Cont) and soil treated with biochar and compost (Cont $+\mathrm{B}$, Cont $+B+R$ ) were added to a filter paper (Whatman No.1) in the dishes. For each plant species, 10 seeds were placed on the filter paper and dishes were placed in the dark at $28^{\circ} \mathrm{C}$. Germination tests were performed with four replicates. The germination percentages with respect to the control (distilled water) and root lengths were determined when the seeds germinated (Table 1 ). The germination index (GI) was calculated as $\mathrm{GI}=\% \mathrm{G}$ * Le/Lc, where \%G is the percentage of germinated seeds in each extract with respect to the control; Le is the mean total root length of the germinated seeds in each extract and Lc is the mean root length of the control. Finally, germination index was classified according to the scale proposed by Zucconi et al. (1985) and Emino and Warman (2004). GI values < 50\% suggest a high phytotoxicity; 50-80\% suggest moderate phytotoxicity and $>80 \%$ suggest no phytotoxicity. When GI exceeds $100 \%$, the material can be considered as a phytonutrient or phytostimulant.

\subsection{Biomass growth experiments}

Five seeds of cress, mustard and $0.10 \mathrm{~g}$ of ryegrass were planted in pots as follows: The bottom pot was filled with $2 \mathrm{~cm}$ height gravel layer and then, $50 \mathrm{~g}$ of different treatments ( $C$, Cont, Cont $+\mathrm{B}$ and Cont $+B+R$ ) were added to each container. Pots were maintained in an incubator with 12:12 light: dark cycles at a controlled temperature of $28{ }^{\circ} \mathrm{C}$ for 1 month and pots were randomly arranged inside the incubator. During this time, samples were regularly watered with distilled water and after 90 days, the roots and shoots were sampled and carefully washed with deionized water. Fresh biomass was immediately weighted and dry mass was assessed after oven drying for $24 \mathrm{~h}$ at $80^{\circ} \mathrm{C}$ and cooling down to room temperature.

Each experiment was performed in triplicate.

\subsection{Soil characterization}

The soil biochar effect was evaluated after the incubation period determining $\mathrm{pH}$ and $\mathrm{EC}$, trace metal mobile forms and microbial biomass.

$\mathrm{pH}$ and $\mathrm{EC}$ were determined as in section 2.2. Although soil was spiked by $\mathrm{Cu}$, the mobile forms of $\mathrm{Cu}, \mathrm{Zn}, \mathrm{Cd}, \mathrm{Pb}$ were determined due to the soil being treated with a composted urban organic waste and urban organic waste biochar, where other heavy metals could be present. The mobile forms of heavy metals were extracted using $0.1 \mathrm{M} \mathrm{CaCl}_{2}$ (Ure et al., 1995) and analyzed with Metrohm voltamperimeter $746 \mathrm{~V}$ A Trace Analyzer with ammonic acetate $0.001 \mathrm{~mol} \mathrm{~L}^{-1}$ and EDTA as supporter electrolyte.

Soil microbial biomass $\mathrm{C}$ (biomass $\mathrm{C}$ ) was determined by the chloroform fumigation-extraction method (Vance et al., 1987). The

Table 1

Crops used for the germination test.

\begin{tabular}{lll}
\hline Common name & Scientific name & Germination time (days) \\
\hline Cress & Lepidium sativum & 2 \\
Mustard & Sinapsis alba & 3 \\
Lentil & Lens culinaris & 2 \\
Lettuce & Lactuca sativa & 2 \\
Tomato & Lycopersicon esculentum & 4 \\
Basil & Ocymum basilicum & 3 \\
Grass & Lolium sp. & 4 \\
Barley & Hordeum vulgare & 2 \\
Wheat & Triticum aestivum & 2 \\
\hline
\end{tabular}

difference in the $C$ content of the fumigated and unfumigated extracts was converted to microbial biomass $C$ (expressed in $\mathrm{mg} \mathrm{kg}^{-1}$ of dry soil) by applying a factor $(\mathrm{Kc})$ of 0.45 . This factor has been previously used by Paz-Ferreiro et al. (2012) in a soil amended with sewage sludge biochar.

\subsection{Statistical analysis}

The statistical analyses (calculation of means and standard deviations, differences of means) were performed using STATGRAPHICS Centurion XVI.II ${ }^{\mathbb{B}}$ software (Statpoing technologies, Warrengton, USA). Differences of means were tested using an analysis of variance (ANOVA). Means were considered to be different when $\mathrm{P}<0.05$ using the Tukey's test.

\section{Results and discussion}

\subsection{Raw materials characterization}

Table 1 summarized the physicochemical properties of the soil (S), compost (R) and biochar (B) used in this study. Soil pH was close to neutrality and presented an EC value of $0.25 \mathrm{dS} \mathrm{m}^{-1}$. The $\mathrm{C}_{\text {oxi }}$ and $\mathrm{N}_{\text {Kjeldhal }}$ were relatively low $(0.63 \%$ and $0.09 \%$, respectively).

The $\mathrm{pH}$ of the compost $(\mathrm{R})$ increased 0.66 units after pyrolysis, an amount which was similar to previous studies (Méndez et al., 2012). Biochar CEC increased $79.76 \%$ with respect to the raw material, which can have a positive effect in trace metal retention. The change in CEC values after pyrolysis depends of the raw material and pyrolysis conditions; for example, Méndez et al. (2012) and Paz-Ferreiro et al. (2012) observed CEC reduction after urban waste pyrolysis while Cely et al. (2015) observed CEC increments after pyrolysis of cattle and chicken manure at similar temperatures. The percentage of $C_{\text {oxi }}$ was greater in the $R$ than in biochar due to more stable carbon structures development during polymerization/ condensation reactions that take place in the pyrolysis process (Calvelo Pereira et al., 2011) and it was related to the percentage of soluble carbon $\left(\mathrm{C}_{\text {oxi soluble }}\right.$ ) that decreased a $76.2 \%$ after thermal treatment. The $\mathrm{N}_{\text {Kjeldahl }}$ content slightly increased following the pyrolysis process (Cely et al., 2015).

Soil phosphorus presented an average value of $276 \pm 19 \mathrm{mg} \mathrm{kg}^{-1}$ while potassium content was $447 \pm 16 \mathrm{mg} \mathrm{kg}^{-1}$. For the compost, the potassium content was $4013 \pm 23 \mathrm{mg} \mathrm{kg}^{-1}$ and increased to $6240 \pm 56 \mathrm{mg} \mathrm{kg}^{-1}$ in the biochar due to salt concentration during pyrolysis and in accordance to the observed EC variation. Finally, the availability of $\mathrm{P}$ decreased with pyrolysis treatment from $1090 \pm 138 \mathrm{mg} \mathrm{kg}^{-1}$ for the compost to $525 \pm 16 \mathrm{mg} \mathrm{kg}^{-1}$ for the biochar.

Table 2 shows proximate analysis for the $\mathrm{R}$ and $\mathrm{B}$ samples. The ash content increased during pyrolysis from $24.81 \%$ for R to $57.67 \%$ for $B$. The volatile matter content represented a higher percentage in the compost with a value of $56.79 \%$, decreasing after pyrolysis to $9.69 \%$. Fixed carbon increased with pyrolysis from $18.40 \%$ for the compost to $35.65 \%$ for the biochar, due to volatilization and polymerization/condensation reactions that take place during pyrolysis. These results were similar to those obtained previously by different authors (Cely et al., 2015; Gascó et al., 2016a).

Combustion profiles of compost and biochars are illustrated in Fig. 1. Weight loss was higher for compost than for biochar (Fig. 1a). In the case of dTG curves (Fig. 1b), three main areas were observed. The first peak was related to sample humidity. Their intensity was higher for $\mathrm{R}$ than for $\mathrm{B}$, indicating that compost absorbs more water than biochar. Then, the second weigh loss region was due to the combustion of the organic matter (Cely et al., 2015). Two main areas were observed: (i) combustion of organic matter like cellulose and hemicellulose that takes place at lower temperatures (from 200 to 
Table 2

Main properties of soil (C), compost (R) and biochar (B).

\begin{tabular}{llll}
\hline & $\mathrm{C}$ & $\mathrm{R}$ & $\mathrm{B}$ \\
\hline Sand (\%) & 85 & - & - \\
Clay (\%) & 6 & - & - \\
Silt (\%) & 9 & - & - \\
Texture & Sandy loam & & \\
$\mathrm{pH}(1: 2.5)$ & $7.73 \pm 0.03$ & $8.39 \pm 0.25$ & $9.35 \pm 0.06$ \\
$\mathrm{EC}\left(1: 2.5 . \mathrm{dS} \mathrm{m}^{-1}\right)$ & $0.25 \pm 0.03$ & $0.26 \pm 0.02$ & $0.44 \pm 0.01$ \\
$\mathrm{C}_{\text {oxi }}(\%)$ & $0.63 \pm 0.02$ & $19.75 \pm 1.76$ & $12.41 \pm 0.34$ \\
$\mathrm{C}_{\text {oxi soluble }}(\%)$ & - & $0.21 \pm 0.04$ & $0.05 \pm 0.00$ \\
$\mathrm{~N}_{\text {kjeldahl }}(\%)$ & $0.09 \pm 0.00$ & $1.25 \pm 0.02$ & $1.34 \pm 0.05$ \\
$\mathrm{CEC}_{(\mathrm{cmol}}\left(\mathrm{kg}^{-1}\right)$ & $8.64 \pm 0.69$ & $30.59 \pm 2.90$ & $54.99 \pm 8.08$ \\
$\mathrm{~K}^{+}\left(\mathrm{mg} \mathrm{kg}^{-1}\right)$ & $447 \pm 25$ & $4013 \pm 23$ & $6240 \pm 56$ \\
$\mathrm{P}\left(\mathrm{mg} \mathrm{kg}^{-1}\right)$ & $276 \pm 19$ & $1090 \pm 138$ & $525 \pm 16$ \\
Proximate analysis & & & \\
Ash (\%) & - & 24.81 & 57.67 \\
Volatile matter $(\%)$ & - & 56.79 & 9.69 \\
Fixed carbon (\%) & - & 18.4 & 32.65 \\
VM/(VM $+\mathrm{FC})$ & - & 75.53 & 22.89 \\
\hline
\end{tabular}

$400{ }^{\circ} \mathrm{C}$ ) and (ii) combustion of organic matter more polymerized, which was produced at higher temperature (Méndez et al., 2011). Finally, at temperatures higher than $600^{\circ} \mathrm{C}$, weight loss was due to carbon refractory combustion, decomposition of clays and carbonates. Main differences between dTG curves of R and B at temperatures higher than $200{ }^{\circ} \mathrm{C}$ were due to organic matter transformation that take place during pyrolysis. It could be observed that the peak related to cellulose combustion decreases from compost to biochar whereas the weight loss continues until higher temperatures due to more ash content and the presence of refractory carbon oxidizing at higher temperatures.

\subsection{Germination tests}

Table 3 shows results from germination test of different species for the different treatments and both materials ( $B$ and $R$ ). It could be observed that biochar was phytostimulating for cress, mustard and lentil; no significant effect was observed for barley; while moderate

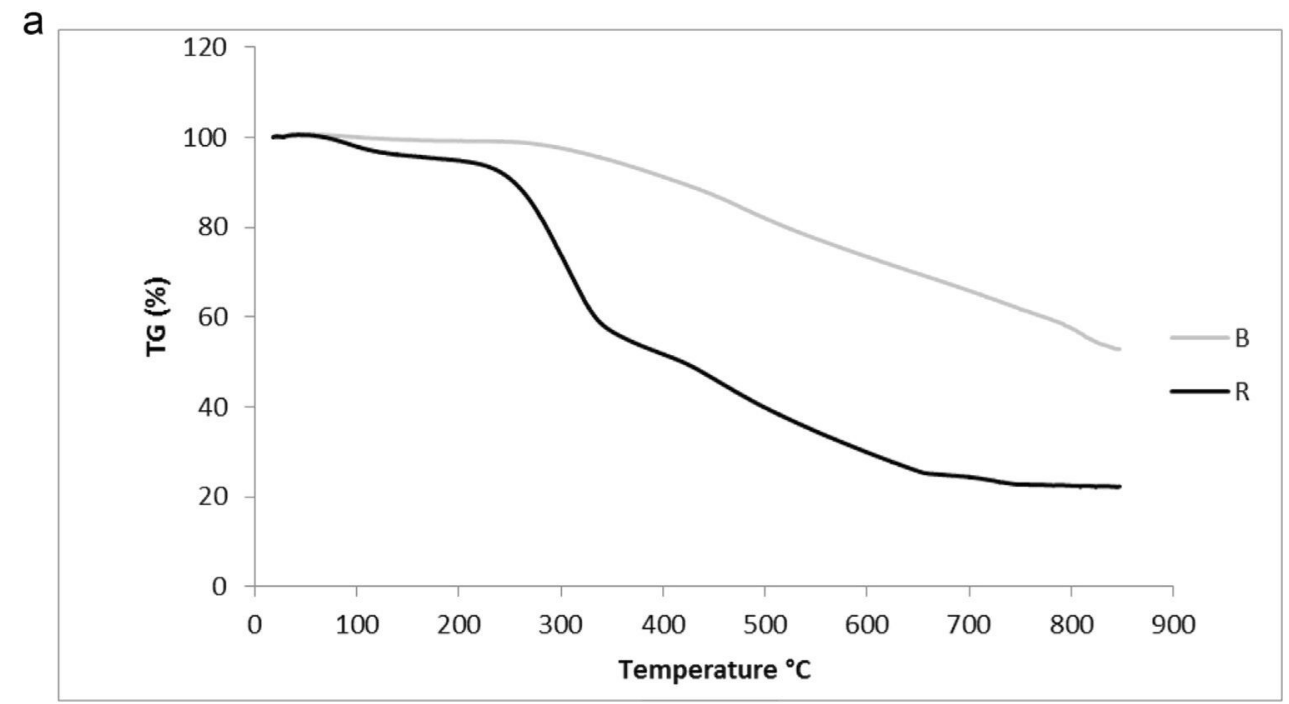

b

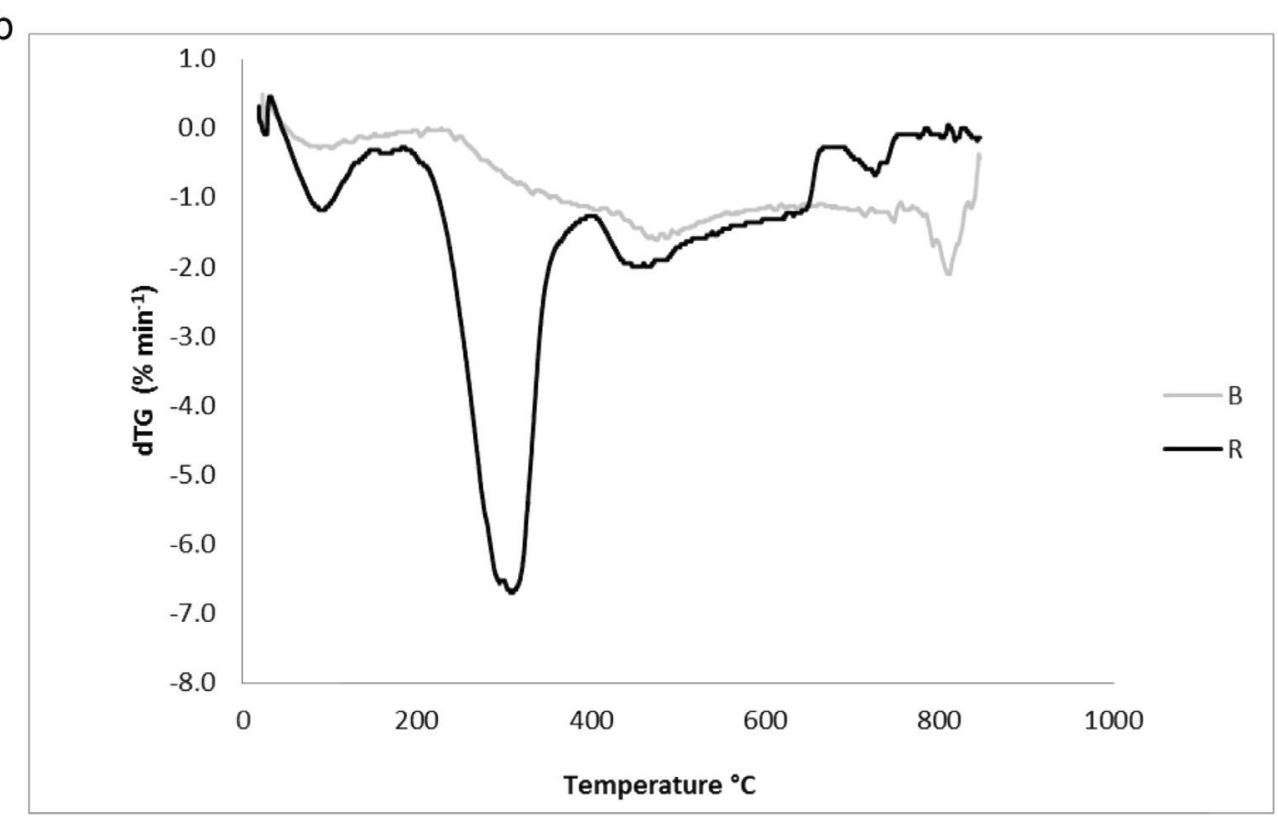

Fig. 1. a. TG curves (\%) for the compost and the biochar (B).

b. dTG $\left(\%\right.$ min $\left.^{-1}\right)$ curves for the compost (R) and the biochar (B). 
Table 3

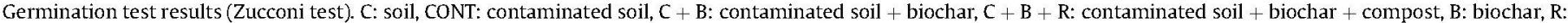

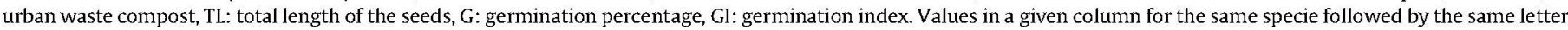
are not significantly different $(\mathrm{p}=0.05)$ using Tukey method.

\begin{tabular}{|c|c|c|c|c|c|}
\hline Species & Treatments & $\mathrm{TL}(\mathrm{cm})$ & $\% \mathrm{G}$ & GI & IG Classification \\
\hline \multirow[t]{6}{*}{ Lepidium sativum/Cress } & C & $2.09 \pm 0.31 b$ & $90 \pm 10$ & $96.37 \pm 4.24 \mathrm{ab}$ & No phytotoxicity \\
\hline & CONT & $1.06 \pm 0.06 a$ & 100 & $55.09 \pm 3.04 c$ & Moderate phytotoxicity \\
\hline & $\mathrm{C}+\mathrm{B}$ & $2.48 \pm 0.01 c$ & 100 & $128.32 \pm 0.60 \mathrm{~d}$ & Phytostimulating \\
\hline & $C+B+R$ & $2.08 \pm 0.11 b$ & 100 & $107.94 \pm 5.82 b$ & Phytostimulating \\
\hline & B & $2.08 \pm 0.06 b$ & $96.67 \pm 5.77$ & $104.32 \pm 9.13 a b$ & Phytostimulating \\
\hline & $\mathrm{R}$ & $1.85 \pm 0.04 b$ & $96.67 \pm 5.77$ & $92.57 \pm 6.39 a$ & No phytotoxicity \\
\hline \multirow[t]{6}{*}{ Sinapsis alba/Mustard } & $\mathrm{C}$ & $0.88 \pm 0.10 \mathrm{a}$ & $60 \pm 17.32$ & $149.04 \pm 23.32 a$ & Phytostimulating \\
\hline & CONT & $0.65 \pm 0.14 a$ & 60 & $112.5 \pm 24.65 \mathrm{a}$ & Phytostimulating \\
\hline & $C+B$ & $1.20 \pm 0.17 a$ & $56.67 \pm 5.77$ & $194.23+17.39 a$ & Phytostimulating \\
\hline & $C+B+R$ & $0.74+0.28 a$ & $50+17.32$ & $105.77+46 a$ & Phytostimulating \\
\hline & B & $0.94 \pm 0.17 a$ & $70 \pm 10$ & $191.35 \pm 48.64 a$ & Phytostimulating \\
\hline & $\mathrm{R}$ & $1.20 \pm 0.57 a$ & $43 . \overline{33} \pm 5.77$ & $148.08 \pm 65.04 \mathrm{a}$ & Phytostimulating \\
\hline \multirow[t]{6}{*}{ Lens culinaris/Lentil } & C & $1.39 \pm 0.26 a$ & 100 & $104.48 \pm 19.24 a$ & Phytostimulating \\
\hline & CONT & $1.49 \pm 0.18 a$ & $90 \pm 10$ & $101.97 \pm 22.05 a$ & Phytostimulating \\
\hline & $C+B$ & $1.33 \pm 0.12 \mathrm{a}$ & $96.67 \pm 5.77$ & $96.95 \pm 11.41 \mathrm{a}$ & No phytotoxicity \\
\hline & $C+B+R$ & $1.44 \pm 0.03 a$ & $93.33 \pm 11.55$ & $101.47 \pm 12.39 a$ & Phytostimulating \\
\hline & B & $1.50 \pm 0.21 \mathrm{a}$ & $96.67 \pm 5.77$ & $109.00 \pm 15.63 \mathrm{a}$ & Phytostimulating \\
\hline & $\mathrm{R}$ & $1.22 \pm 0.15 a$ & $93.33 \pm 11.55$ & $85.14 \pm 11.75 a$ & No phytotoxicity \\
\hline \multirow[t]{6}{*}{ Lactuca sativa/Lettuce } & C & $1.44 \pm 0.05 c$ & 90 & $107.48 \pm 4.10 a$ & Phytostimulating \\
\hline & CONT & $0.73 \pm 0.09 a$ & $96.67 \pm 5.77$ & $58.17 \pm 5.05 c d$ & Moderate phytotoxicity \\
\hline & $C+B$ & $1.26 \pm 0.04 c$ & $93.33 \pm 11.55$ & $98.34 \pm 15.35 a b$ & No phytotoxicity \\
\hline & $\mathrm{C}+\mathrm{B}+\mathrm{R}$ & $1.38 \pm 0.15 c$ & $83.33 \pm 5.77$ & $95.57 \pm 8.76 \mathrm{ab}$ & No phytotoxicity \\
\hline & B & $1.00 \pm 0.08 b$ & $86.67 \pm 15.28$ & $72.58 \pm 18.38 b c$ & Moderate phytotoxicity \\
\hline & $\mathrm{R}$ & $0.90 \pm 0.08 a b$ & $53.33 \pm 5.77$ & $39.89 \pm 5.45 \mathrm{~d}$ & High phytotoxicity \\
\hline \multirow[t]{6}{*}{ Lycopersicon esculentum/Tomato } & $c$ & $0.82 \pm 0.10 a$ & $70 \pm 17.32$ & $122.86+20.73 a$ & Phytostimulating \\
\hline & CONT & $0.49 \pm 0.03 a$ & $66.67 \pm 5.77$ & $71.97 \pm 9.99 a$ & Moderate phytotoxicity \\
\hline & $C+B$ & $0.70 \pm 0.06 a$ & $66.67 \pm 15.28$ & $101.05 \pm 15.78 \mathrm{a}$ & Phytostimulating \\
\hline & $C+B+R$ & $0.72 \pm 0.31 a$ & $53.33 \pm 20.82$ & $77.06 \pm 31.56 a$ & Moderate phytotoxicity \\
\hline & B & $0.53 \pm 0.06 a$ & 10 & $11.63 \pm 1.26 \mathrm{~b}$ & High phytotoxicity \\
\hline & $\mathrm{R}$ & $0.65 \pm 0.05 a$ & $16.67 \pm 5.77$ & $23.26 \pm 7.01 \mathrm{~b}$ & High phytotoxicity \\
\hline \multirow[t]{6}{*}{ Ocymum basilicum/Basil } & C & $0.66 \pm 0.01 \mathrm{e}$ & 100 & $100.51 \pm 1.75 a$ & Phytostimulating \\
\hline & CONT & $0.37 \pm 0.02 a$ & $96.67 \pm 5.77$ & $53.53 \pm 5.32 \mathrm{~d}$ & Moderate phytotoxicity \\
\hline & $C+B$ & $0.55 \pm 0.03 \mathrm{ce}$ & $96.67 \pm 5.77$ & $81.31 \pm 7.63 b c$ & No phytotoxicity \\
\hline & $C+B+R$ & $0.63 \pm 0.05 \mathrm{ed}$ & $96.67 \pm 5.77$ & $91.62 \pm 10.64 \mathrm{ab}$ & No phytotoxicity \\
\hline & B & $0.44 \pm 0.03 \mathrm{ab}$ & $73.33 \pm 5.77$ & $48,48 \mathrm{~d}$ & High phytotoxicity \\
\hline & $\mathrm{R}$ & $0.49 \pm 0.03 b c$ & $86.67 \pm 5.77$ & $64.15 \pm 6.83 \mathrm{~cd}$ & High phytotoxicity \\
\hline \multirow[t]{6}{*}{ Lolium sp./Ryegrass } & C & $1.16 \pm 0.22 \mathrm{ab}$ & 90 & $127.03 \pm 23.93 a b$ & Phytostimulating \\
\hline & CONT & $0.67 \pm 0.03 a$ & $83.33 \pm 5.77$ & $68.59 \pm 8.11 \mathrm{a}$ & Moderate phytotoxicity \\
\hline & $\mathrm{C}+\mathrm{B}$ & $1.49 \pm 0.25 b$ & $83.33 \pm 15.28$ & $148.95 \pm 10.50 b$ & Phytostimulating \\
\hline & $C+B+R$ & $1.11+0.28 a b$ & 100 & $135.55 \pm 34.21 b$ & Phytostimulating \\
\hline & B & $1.00 \pm 0.06 \mathrm{ab}$ & 90 & $109.17+6.71 \mathrm{ab}$ & Phytostimulating \\
\hline & $\mathrm{R}$ & $1.08+0.17 \mathrm{ab}$ & $76.67 \pm 15.28$ & $102.27 \pm 33.37 \mathrm{ab}$ & Phytostimulating \\
\hline \multirow[t]{6}{*}{ Triticum aestivum/Wheat } & C & $1.57 \pm 0.12 b c$ & 100 & $89.89 \pm 7.15 a b$ & No phytotoxicity \\
\hline & CONT & $1.01 \pm 0.04 a$ & $96.67 \pm 5.77$ & $56.11 \pm 3.19 c$ & Moderate phytotoxicity \\
\hline & $C+B$ & $1.58 \pm 0.05 b c$ & 100 & $90.27 \pm 2.58 \mathrm{ab}$ & No phytotoxicity \\
\hline & $C+B+R$ & $1.71 \pm 0.07 c$ & 100 & $97.90 \pm 4.01 \mathrm{~b}$ & No phytotoxicity \\
\hline & B & $1.32 \pm 0.18 b$ & 100 & $75.76 \pm 10.18 \mathrm{a}$ & Moderate phytotoxicity \\
\hline & $\mathrm{R}$ & $1.46 \pm 0.12 b c$ & 90 & $75.00 \pm 6.03 \mathrm{a}$ & Moderate phytotoxicity \\
\hline \multirow[t]{6}{*}{ Hordeum vulgare/Barley } & C & $1.72 \pm 0.31 \mathrm{a}$ & $86.67 \pm 11.55$ & $94.27 \pm 17.13 \mathrm{ab}$ & No phytotoxicity \\
\hline & CONT & $1.35 \pm 0.09 a$ & 100 & $86.20 \pm 5.71 \mathrm{ab}$ & No phytotoxicity \\
\hline & $C+B$ & $1.62 \pm 0.21 \mathrm{a}$ & 100 & $103.40 \pm 13.09 \mathrm{ab}$ & Phytostimulating \\
\hline & $C+B+R$ & $1.88 \pm 0.08 \mathrm{a}$ & $95.00 \pm 7.07$ & $114.02 \pm 13.51 \mathrm{~b}$ & Phytostimulating \\
\hline & B & $1.39 \pm 0.11 \mathrm{a}$ & 100 & $88.75 \pm 7.24 \mathrm{ab}$ & No phytotoxicity \\
\hline & $\mathrm{R}$ & $1.42 \pm 0.17 a$ & $83.33 \pm 5.77$ & $75.37 \pm 11.58 \mathrm{a}$ & Moderate phytotoxicity \\
\hline
\end{tabular}

phytotoxicity was found for lettuce and wheat and high phytotoxicity for basil and tomato. On the contrary, compost R showed high phytotoxicity for lettuce, tomato and basil and was only phytostimulating for ryegrass and mustard. For the remaining species tested, compost showed no phytotoxicity or moderate phytotoxicity. It could be concluded that pyrolysis of compost decreases phytotoxicity for 4 of 9 species studied, indicating that pyrolysis at moderate temperatures $\left(500{ }^{\circ} \mathrm{C}\right)$ could be an interesting alternative for the treatment of organic wastes decreasing the presence of phytotoxic compounds. This fact is consistent with Nieto et al. (2016) who found higher GI values when the pyrolysis temperature increased from 300 to $500{ }^{\circ} \mathrm{C}$. According to Zucconi et al. (1985) and Emino and Warman (2004), copper contaminated soil presents phytotoxicity for cress, lettuce, tomato, lettuce, basil, ryegrass and barley. In spite of the elevated copper concentration, the contaminated soil solution was phytostimulating for mustard and lentil. Mustard was proposed as Cu resistant by Mackie et al. (2014) and Chigbo et al. (2013). These authors also propose other species of the mustard family (genera Brassica and Sinapsis), such as $B$. juncea commonly known as brown mustard and $B$. napus (turnip) as copper resistant. In general, the use of biochar had a positive effect on seed germination, especially for cress and ryegrass. The combined use of biochar and compost also had a phytostimulating effect for the different plant species used in this work, except for tomato which shows moderate phytotoxicity.

Root growth is more sensitive than shoot growth to the 

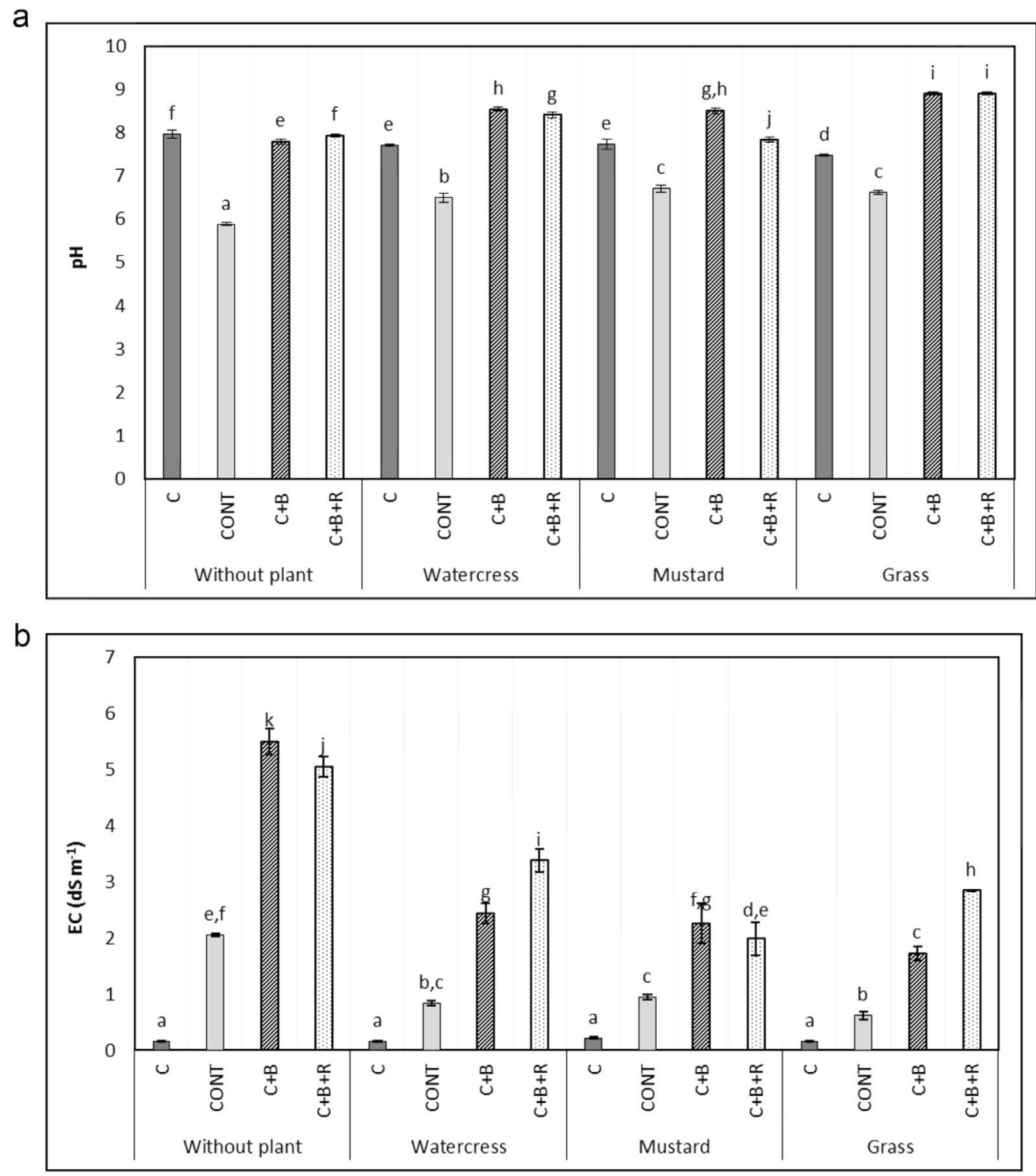

Fig. 2. a. $\mathrm{pH}$ of treatments. Values followed by the same letter are not significantly different $(\mathrm{P}<0.05)$ using Tukey method. b. EC of treatments. Values followed by the same letter are not significantly different $(\mathrm{P}<0.05)$ using Tukey method.

detrimental impact of heavy metal in soils. Excessive amounts of copper uptaken by plants can interfere with numerous metabolical processes, including enzyme activity, protein oxidation, membrane integrity and leading to DNA alterations. These processes would cause growth inhibition of plant. Copper accumulates primarily in the root tissue with little translocated to the shoots. Evidences of $\mathrm{Cu}$ toxicity on root growth include a reduction in the number and length of root hairs and damage to the root cuticle. In our study, different trends were observed depending on the plant species. For cress, lettuce and wheat, the growth was inhibited in the contaminated soils and promoted in soils amended with biochar or biochar plus compost reaching similar values to the control soil. Wheat root growth inhibition by copper pollution has been reported before (Zhang et al., 2008). This has been also the case for lettuce (Inaba and Takenaka, 2005). For mustard, lentil, tomato, basil and barley, there were not significant differences between treatments and finally, the addition of B or R on soil did not lead any effect on ryegrass.

\subsection{Effects of biochar addition, compost and plant growth in soil properties}

Cress, mustard and ryegrass were grown during 4 weeks on different treatments ( $C$, Cont, Cont $+B$, Cont $+B+R$ ). As a reference, soil samples were incubated in the same conditions without any species being grown. Fig. $2 \mathrm{a}$ shows that the control soil $\mathrm{pH}$ decreased to 5.88 after its contamination with an acidic sulphate copper solution. The addition of $\mathrm{B}$ and $\mathrm{B}+\mathrm{R}$ increased the $\mathrm{pH}$ to values close to those of the original uncontaminated soil. The $\mathrm{pH}$ variation was different in polluted soil treated with biochar and compost following the growth of vegetable species. The $\mathrm{pH}$ increases were higher in soils treated with biochar and biochar plus compost when cress or ryegrass were planted, followed by soil planted with mustard. The treatment $\mathrm{B}+\mathrm{R}$ increased the $\mathrm{pH}$ to a value of 9 .

Figure $2 \mathrm{~b}$ showed that EC increased significantly after pollution with copper sulphate solution (from $0.16 \mathrm{dS} \mathrm{m}^{-1}$ to $2.05 \mathrm{dS} \mathrm{m}^{-1}$ ) and especially after addition of biochar and biochar plus compost. 


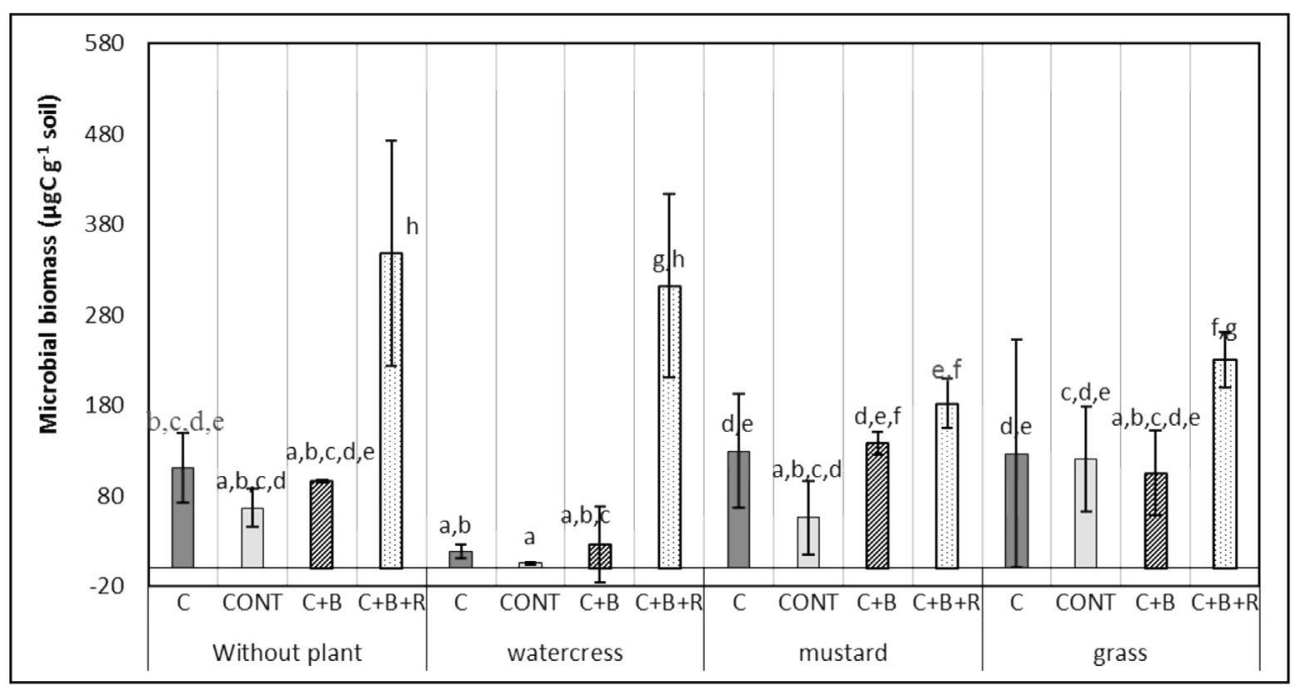

Fig. 3. Microbial biomass of treatments. Values followed by the same letter are not significantly different (P $<0.05)$ using Tukey method.

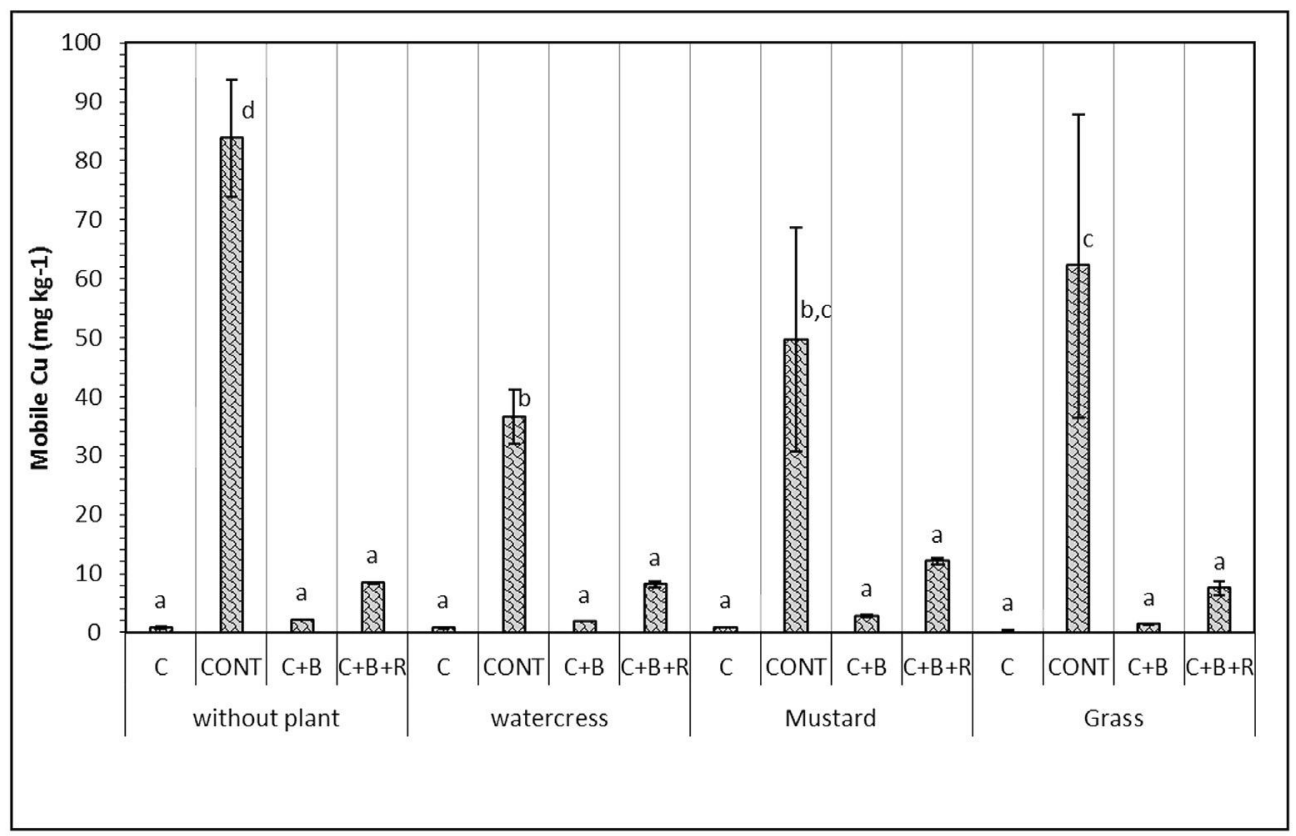

Fig. 4. Mobile copper (Cu). Values followed by the same letter are not significantly different $(\mathrm{P}<0.05)$ using Tukey method.

The growth of vegetable species decreased EC in the contaminated soil and in the contaminated soil treated with biochar and compost. This reduction was more marked in Cont $+B$ planted with ryegrass and Cont $+\mathrm{B}+\mathrm{R}$ following mustard growth. The lowest reduction was observed in soil treated with $B+R$ after cress growth.

Heavy metals exhibit toxic effects towards soil biota, impairing soil microbial activity. The decrease in the number and activity of soil microbiota will have a negative effect on soil nutrient cycling and other processes mediated by soil microorganisms. Soil microorganisms respond quickly to changes in the soil habitat and precede detectable changes in other soil properties. Thus, soil biological properties, and in particular, microbial biomass, have been monitored in land restoration.

We did not observe any deleterious effect of soil contamination with copper on microbial biomass (Fig. 3). This was in spite of our concentrations of $\mathrm{Cu}$ being higher than the threshold which can affect soil functions (100-150 $\mathrm{mg} \mathrm{kg}^{-1}$, Ippolito et al., 2010). However, microbial biomass values rose considerably in the soil treated with biochar and compost, but not with biochar alone (Fig. 3). This result highlights the difference in lability between the carbon contained in the compost and in the biochar, which can be seen in Fig. 1. Thus, there is a small amount of carbon available in the biochar for the soil microorganisms to metabolize. The fraction of labile carbon, available to the soil organisms is larger in compost, and this results in a greater microbial biomass when both amendments are applied in conjunction.

\subsection{Effects of biochar addition on copper mobility}

Fig. 4 shows the mobile concentration of copper in the soil samples. In the unplanted control a strong increment of $\mathrm{Cu}$ mobile concentration was observed after its contamination with copper 


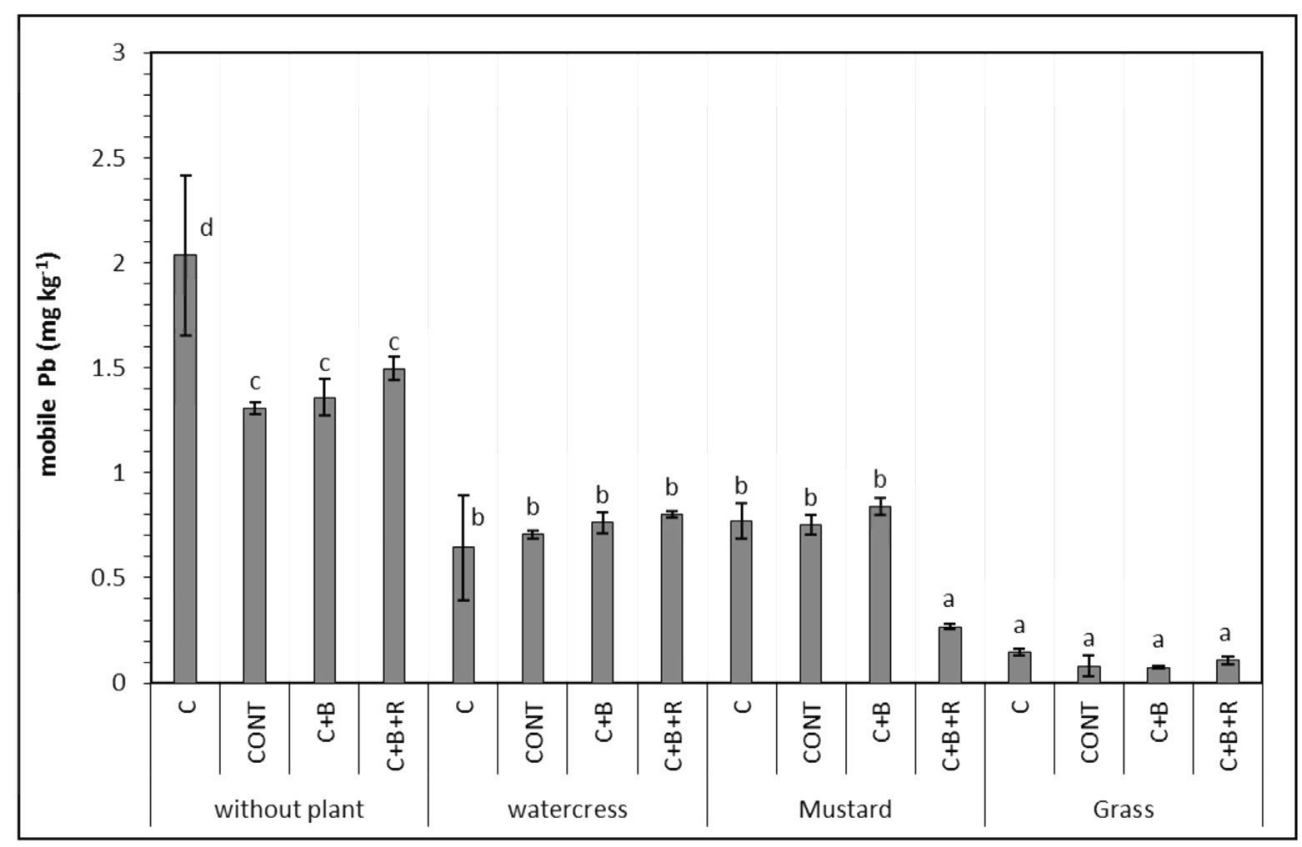

Fig. 5. Mobile lead (Pb). Values followed by the same letter are not significantly different $(\mathrm{P}<0.05)$ using Tukey method.

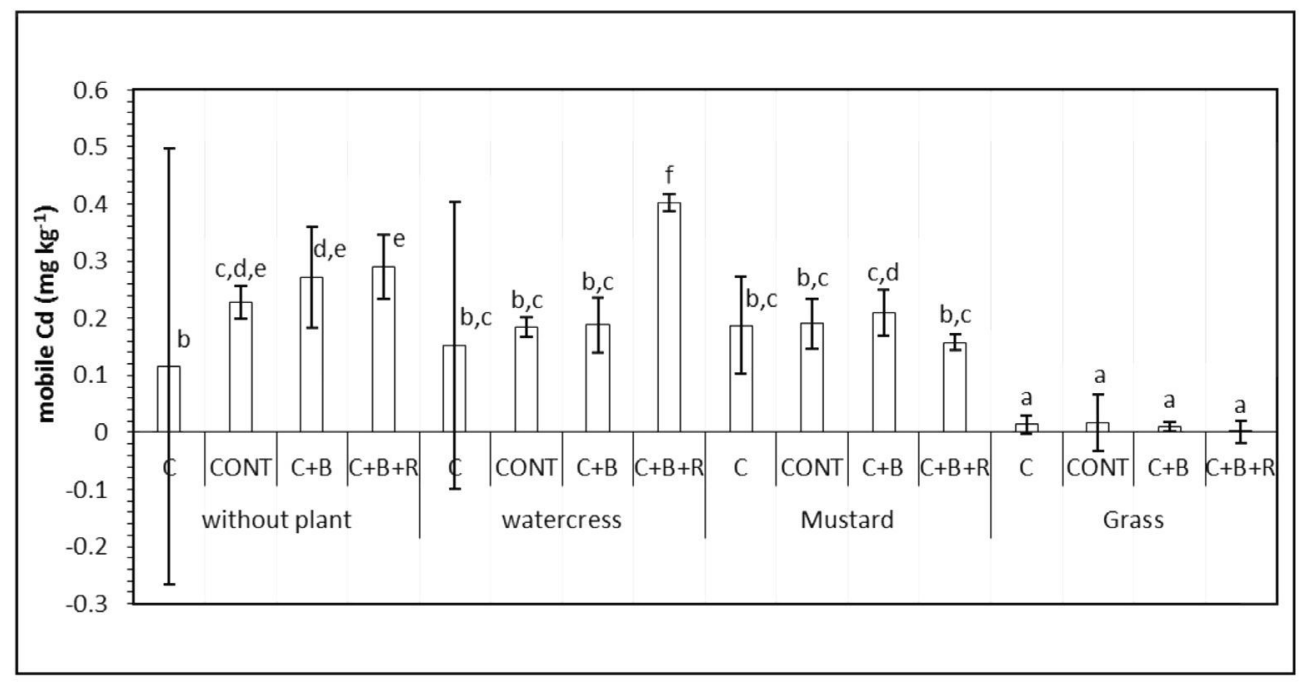

Fig. 6. Mobile cadmium (Cd). Values followed by the same letter are not significantly different $(\mathrm{P}<0.05)$ using Tukey method.

Table 4

Plant biomass for Cress, Mustard and Ryerass. Values followed by the same letter are not significantly different $(\mathrm{p}=0.05)$ using Tukey method.

\begin{tabular}{lll}
\hline Plants & Treatment & Dry weight $80^{\circ} \mathrm{C}(\mathrm{g})$ \\
\hline Watercress & $\mathrm{C}$ & $0.42 \pm 0.16 \mathrm{~b}$ \\
& CONT & $-\mathrm{b}$ \\
& $\mathrm{C}+\mathrm{B}$ & $0.02 \pm 0.02^{\mathrm{a}} \mathrm{a}$ \\
Mustard & $\mathrm{C}+\mathrm{B}+\mathrm{R}$ & $0.04 \pm 0.02 \mathrm{a}$ \\
& $\mathrm{C}$ & $0.02 \pm 0.03^{\mathrm{a}} \mathrm{a}$ \\
& $\mathrm{CONT}$ & - \\
Grass & $\mathrm{C}+\mathrm{B}$ & $0.02 \pm 0.00 \mathrm{a}$ \\
& $\mathrm{C}+\mathrm{B}+\mathrm{R}$ & - \\
& $\mathrm{C}$ & $0.84 \pm 0.56 \mathrm{c}$ \\
& $\mathrm{CONT}$ & $0.21 \pm 0.01 \mathrm{ab}$ \\
& $\mathrm{C}+\mathrm{B}$ & $0.17 \pm 0.11 \mathrm{ab}$ \\
& $\mathrm{C}+\mathrm{B}+\mathrm{R}$ & $0.09 \pm 0.01 \mathrm{ab}$ \\
\hline
\end{tabular}

a In these cases the seeds of one of the replicates did not germinate.

b There was no plant growth. solution, which may be mainly due to the low CEC of the soil, thus being unable to retain copper, and to the acid $\mathrm{pH}$. Addition of $\mathrm{B}$ and $\mathrm{B}+\mathrm{R}$ to soil had an important impact on copper mobility, diminishing the concentration of mobile copper to the levels of the control soil. This suggests that the high $\mathrm{pH}$ and the increment of CEC provided by the biochar and compost amendment reduced the copper mobility in soils (Rodríguez-Vila et al., 2015). This effect is also observed in pots planted with cress, mustard and ryegrass. Those species, even without biochar addition decreased copper mobility, following the order from the highest to the lowest: Cress, mustard and ryegrass.

After growth of plants in polluted soils treated with $B$ and $B+R$, a salt film was observed around the pots. DRFX analysis of salts was performed indicating that it was mainly composed of $\mathrm{NaCl}$ with lower amounts of $\mathrm{CaPO}_{3}$ and $\mathrm{NaAlSiO}_{4}$. This demonstrates that cation exchange reactions take place after addition of biochar and 
compost to copper polluted soil.

Fig. 5 shows mobile lead concentration values in the planted and unplanted treatments. In the unplanted soil, a decrease in mobile lead concentration in comparison with the control soil was observed. This is because soil contamination with an acid dissolution of copper sulphate $\left(\mathrm{CuSO}_{4}\right)$ will possibly derive in the formation of insoluble lead sulphate $\left(\mathrm{PbSO}_{4}\right)$. In general, no differences in mobile $\mathrm{Pb}$ among the different treatments $(\mathrm{C}, \mathrm{CONT}, \mathrm{C}+\mathrm{B}$ and $\mathbf{C}+\mathbf{B}+\mathrm{R}$ ) were observed in soils planted with cress, ryegrass and mustard. The exception was the $\mathrm{C}+\mathrm{B}+\mathrm{R}$ treatment planted with mustard. Mobile cadmium (Fig. 6) was present in smaller amounts than lead in the soil. It is noticeable the larger value of mobile $\mathrm{Cd}$ in the soil planted with cress and amended with biochar and compost. Planting ryegrass decreased the risk posed by cadmium mobility in soils amended with urban waste compost or biochar.

\subsection{Effects of biochar and compost addition in plant biomass of cress, mustard and grass}

As shown in Table 4, grass was the only species that grows in artificial contaminated soil being then resistant, while cress and mustard did not germinate. Specifically, in the case of cress, plants weight was higher in the control soil, while there was no statistically significant difference between both amendments. This trend is repeated in all plant species, with the highest value of plant biomass attained in the control soil planted with ryegrass $(0.84 \pm 0.56 \mathrm{~g})$.

\section{Conclusions}

The presence of vegetable species, especially ryegrass reduced soil electrical conductivity. With respect to biomass growth of vegetable species in copper polluted soil, only ryegrass had a satisfactory productivity in the untreated contaminated soil. Grass can be catalogued as a resistant species to copper presence in those concentrations ( $1000 \mathrm{mg} \mathrm{Cu}^{2+} \mathrm{kg}^{-1}$ of soil). Biochar presence did not increase biomass production but does generate higher root development. For mustard, biomass growth was only observed after biochar addition while the addition of biochar and its mixture with compost had a positive effect for cress growth.

Both, biochar applied alone and biochar with compost were able to immobilize soil $\mathrm{Cu}$ in an artificially polluted soil. Biochar and compost is recommended to be added together in coppercontaminated soils, as this was the only treatment which was able to enhance soil microbial biomass. Thus, it is expected biochar and compost together will improve ecosystems services delivered by soil microbiota.

\section{Acknowledgements}

Authors want to acknowledge Economy and Competitiveness Ministry of Spain for the financial support (CGL2014-58322-R).

\section{References}

Bolan, N., Kunhikrishnan, A., Thangarajan, R., Kumpiene, J., Park, J., Makino, T., Kirkham, M.B., Scheckel, K., 2014. Remediation of heavy metal(loid)s contaminated soils - to mobilize or to immobilize? J. Hazard. Mater 266, 141-161.

Bouyoucos, G.J., 1962. Hydrometer method improved for making particle size analyses of soil. Agron. J. 54, 464-465.

Bremner, J.M., Sparks, D.L., Page, A.L., Helmke, P.A., Loeppert, R.H., Soltanpour, P.N.M., 1996. Nitrogen-total. In: Sparks, D.L., Bartels, J.M., Bigham, J.M. (Eds.), Methods of Soil Analysis. Part 3. Chemical Methods. Soil Science Society of America, Madison, Wisconsin, pp. 417-435.

Calvelo Pereira, R., Kaal, J., Camps Arbestain, M., Pardo Lorenzo, R., Aitkenhead, W. Hedley, M., Macías, F., Hindmarsh, J., Maciá-Agulló, J., 2011. Contribution to characterisation of biochar to estimate the labile fraction of carbon. Org. Geochem. 42, 1331-1342.
Cao, X., Dermatas, D., Xu, X., Shen, G., 2008. Immobilization of lead in shooting range soil by means of cement, quicklime and phosphate amendments. Environ. Sci. Pollut. Res. Int. 15, 120-127.

Cely, P., Gascó, G., Paz-Ferreiro, J., Méndez, A., 2015. Agronomic properties of biochars from different manure wastes. J. Anal. Appl. Pyrol. 111, 173-182.

Chigbo, C., Batty, L., Bartlett, R., 2013. Interactions of copper and pyrene on phytoremediation potential of Brassica juncea in copper-pyrene co-contaminated soil. Chemosphere 90, 2542-2548.

Greamer, R.E., Schulte, R.P.O. Stone, D. Gal, A., Krogh, P.H., Lo Papa, G., Murray, PJ. Peres, G., Foerster, B., Rutgers, M., Sousa, J.P., Winding, A., 2014. Measuring soil basal respiration across Europe: do incubation temperature and incubation time matter? Ecol. Indic. 36, 409-418.

Déportes, I., Benoit-Guyod, J.L., Zmirou, D., 1995. Hazard to man and the environment posed by the use of urban waste compost: a review. Sci. Total Environ. 172, $197-222$.

Emino, E.R., Warman, P.R., 2004. Biological assay for compost quality. Compost Sci. Util. $12,342-348$

Gascó, G., Paz-Ferreiro, J., Cely, P., Plaza, C., Méndez, A., 2016a. Influence of pig manure and its biochar on soil $\mathrm{CO}_{2}$ emissions and soil enzymes. Ecol. Eng. 95, $19-24$.

Gascó, G., Cely, P., Paz-Ferreiro, J., Plaza, C., Méndez, A., 2016b. Relation between biochar properties and effects on seed germination and plant development. Biol. Agric. Hortic. 32, 237-247.

Hargreaves, J.C., Adl, M.S., Warman, P.R., 2008. A review of the use of composted municipal solid waste in agriculture. Agric. Ecosyst. Environ. 123, 1-14.

Inaba, S., Takenaka, C., 2005. Effects of dissolved organic matter on toxicity and bioavailability of copper for lettuce sprouts. Environ. Int. 31, 603-608.

Ippolito, J.A., Ducey, T., Tarkalson, D., 2010. Copper impacts on corn, soil extractability, and the soil bacterial community. Soil Sci. 175, 586-592.

Karami, N., Clemente, R., Moreno-Jiménez, E., Lepp, N.K., Beesley, B., 2011. Efficiency of green waste compost and biochar soil amendment for reducing lead and copper mobility and uptake to ryegrass. J. Hazard. Mater. 191, 41-48.

Kolbas, A., Kidd, P., Guinberteau, J., Jaunatre, R., Herzig, R., Mench, M., 2015 Endophytic bacteria take the challenge to improve $\mathrm{Cu}$ phytoextraction by sunflower. Environ. Sci. Pollut. Res. 22, 5370-5382.

Lehmann, J., Rillig, M.C., Thies, J., Masiello, C.A., Hockaday, W.C., Crowley, D., 2011. Biochar effects on soil biota - a review. Soil Biol. Biochem. 43, 1812-1836.

Liang, C., Zhu, X., Fu, S., Méndez, A., Gascó, G., Paz-Ferreiro, I., 2014. Biochar alters the resistance and resilience to drought in a tropical soil. Environ. Res. Lett. 9 , 064013.

Lu, A., Zhang, S., Shan, X.Q., 2005. Time effect on the fractionation of heavy metals in soils. Geoderma 125, 225-234.

Lu, H., Li, Z., Fu, S., Méndez, A., Gascó, G., Paz-Ferreiro, J., 2014. Can biochar and phytoextractors be jointly used for cadmium remediation? PLoS One 9, e95218.

Mackie, K.A., Schmidt, H.P., Müller, T., Kandeler, E., 2014. Cover crops influence soil microorganisms and phytoextraction of copper from a moderately contaminated vineyard. Sci. Total Environ. 500-501, 34-43.

Mc Bridge, M., Tiller, K., Merry, R., 1981. Copper in Soils and Plants. Academic Press, Sidney.

Méndez, A., Paz-Ferreiro, J., Gil, E., Gascó, G., 2015. The effect of paper sludge and biochar addition on brown peat and coir based growing media properties. Sci. Hortic. 193, 225-230.

Méndez, A., Barriga, S., Guerrero, F., Gascó, G., 2011. Thermal analysis of growing media obtained from mixtures of paper mill waste materials and sewage sludge. J. Therm. Anal. Calorim. 104, 213-221.

Méndez, A., Paz-Ferreiro, J., Araujo, F., Gascó, G., 2014. Biochar from pyrolysis of deinking paper sludge and its use in the treatment of a nickel polluted soil. I. Anal. Appl. Pyrol. 107, 46-52.

Méndez, A., Gómez, A., Paz-Ferreiro, J., Gascó, G., 2012. Effects of sewage sludge biochar on plant metal availability after application to a Mediterranean soil. Chemosphere 89, 1354-1359.

Nieto, A., Gascó, G., Paz-Ferreiro, J., Fernández, J.M., Plaza, C., Méndez, A., 2016. The effect of pruning waste and biochar addition on brown peat based growing media properties. Sci. Hortic. 199, 142-148.

Nelson, D.W. Sommers, L.E, 1996. Total carbon, organic carbon and organic matter. In: Sparks, D.L., Bartels, J.M., Bigham, J.M. (Eds.), Methods of Soil Analysis. Part 3. Chemical Methods. Soil Science Society of America, Madison, Wisconsin, pp. 961-1010.

Oorts, K., Smolders, E., Degryse, F., Buekers, J., Gasco, G., Cornelis, G., Mertens, J. 2008. Solubility and toxicity of antimony trioxide $\left(\mathrm{Sb}_{2} \mathrm{O}_{3}\right)$ in soil. Environ. Sci. Technol. 42, 4378-4383.

Paz-Ferreiro, J., Gascó, G., Gutiérrez, B., Méndez, A., 2012. Soil biochemical activities and the geometric mean of enzyme activities after application of sewage sludge and sewage sludge biochar to soil. Biol. Fertil. Soils 48, 511-517.

Paz-Ferreiro, J., Lu, H., Fu, S., Méndez, A., Gascó, G., 2014. Use of phytoremediation and biochar to remediate heavy metal polluted soils: a review. Solid Earth 5 , $65-75$.

Park, J.H., Choppala, G., Lee, S.J., Bolan, N., Chung, J.W., Edraki, M., 2013. Comparative sorption of $\mathrm{Pb}$ and $\mathrm{Cd}$ by biochars and its implication for metal immobilization in soils. Water Air Soil Pollut. 224, 1-12.

Ramos, M.C., 2006. Metals in vineyard soils of the Penedes area (NE Spain) after compost application. J. Environ. Manage 78, 209-215.

Rodríguez-Vila, A., Covelo, E.F., Forján, R., Asensio, A., 2015. Recovering a copper mine soil using organic amendments and phytomanagement with Brassica juncea L. J. Environ. Manage 147, 73-80. 
Soil Survey Staff, 2014. Keys to Soil Taxonomy. Natural Resources Conservation Service, twelfth ed. United States Department of Agriculture.

Sumner, M., Miller, W., 1996. Cation exchange capacity and exchange coefficients In: Sparks, D.L., Bartels, J.M., Bigham, J.M. (Eds.), Methods of Soil Analysis. Part 3. Chemical Methods. Soil Science Society of America, Madison, Wisconsin, pp. 1201-1229.

Ure, A.M., Davidson, C.M., Thomas, R.P., 1995. Single and sequential extraction schemes for trace metal speciation in soil and sediment. Qual. Assur. Environ. Anal. 20, 505-523.

Vaca-Paulín, R., Esteller-Alberich, M.V., Lugo-de la Fuente, J., Zavaleta-Mancera, H.A., 2006. Effect of sewage sludge or compost on the sorption and distribution of copper and cadmium in soil. Waste Manage. 26, 71-81.

Vacca, A., Bianco, M.R., Murolo, M., Violante, P., 2012. Heavy metals in contaminated soils of the rio sitzerri floodplain (sardinia, Italy): characterization and impact on pedodiversity. Land Degrad. Dev. 23, 350-364.

Vance, E.D., Brookes, P.C., Jenkinson, D.S., 1987. An extraction method for measuring soil microbial biomass. Soil Biol. Biochem. 19, 703-707.

Venegas, A., Rigol, A., Vidal, M., 2015. Viability of organic wastes and biochars as amendments for the remediation of heavy metal-contaminated soils. Chemosphere 119, 190-198.

Watanabe, F.S., Olsen, S.R., 1965. Test of an ascorbic acid method for determining phosphorus in water and $\mathrm{NaHCO}_{3}$ extracts from soils. Soil Sci. Soc. Am. Proc. 29 $677-678$.

Yang, D., Zeng, D.H., Zhang, I., Li, L.J., Mao, R., 2012. Chemical and microbial properties in contaminated soils around a magnesite mine in northeast China. Land Degrad. Dev. 23, 256-262.

Zhang, H., Hu, L.Y., Hu, K.D., He, Y.D., Wang, S.H., Luo, J.P., 2008. Hydrogen sulphide promotes wheat seed germination and alleviates oxidative damage against copper stress. J. Integr. Plant Biol. 50, 1518-1529.

Zhang, X., Wang, H., He, L., Lu, K., Sarmah, A., Li, J., Bolan, N.S., Pei, J., Huang, H., 2013. Using biochar for remediation of soils contaminated with heavy metals and organic pollutants. Environ. Sci. Pollut. Res. Int. 20, 8472-8483.

Zucconi, F., Monaco, A., Forte, M., De Bertoldi, M., 1985. Phytotoxins during the stabilization of organic matter. In: Gasser, J.K.R. (Ed.), Composting of Agricultural and Other Wastes. Elsevier, London. 